\title{
Estimating Reference Emission Level and Project Emission Level for REDD+ Projects in Tropical Forests
}

\author{
Nophea Sasaki ${ }^{1,2, *}$ \\ 1 Graduate School of Applied Informatics, University of Hyogo / 6F, 7-1-28 Minatojima-minamimachi, \\ Chuo-ku, Kobe 650-0047, Japan \\ 2 Harvard Forest, Harvard University, MA, USA \\ *: Corresponding author’s e-mail: nopsasaki@gmail.com or nop.kankyo@ai.u-hyogo.ac.jp
}

\begin{abstract}
The REDD+ scheme of the United Nations Framework Convention on Climate Change is a carbon-based compensation for projects that resulted in reducing carbon emissions or enhancing carbon sinks or both in tropical forests. However, estimating such emissions and sinks remains challenging, and thus making it impossible to estimate carbon revenues from managing tropical forests. Here, we estimated the reduced emissions and sinks by developing models for setting Reference Emission Level (REL) and Project Emission Level (PEL) for REDD+ projects in concession forests taking emissions under conventional logging (CVL) scenario as that of REL, and emissions under reduced impact logging (RIL) and RIL with liberation treatment (RIL+) scenarios as that of PEL. By choosing Cambodia as a case study, REL under the current logging system of 25-year cutting cycle was estimated at $23.1 \mathrm{TgCO}^{2}$ year $^{-1}$. To determine an appropriate cutting cycle, we tested our models with four cutting cycles and found that a 50-year cutting cycle is more appropriate. Taking this 50-year cutting cycle for REDD+ project, PELs were estimated at $0.4 \mathrm{TgCO}_{2}$ and $-3.3 \mathrm{TgCO}_{2}$ year ${ }^{-1}$ under RIL and RIL+, respectively (- means sinks). After subtracting REL with PEL and leakages, annual carbon credits from managing 3.4 million ha of concession forests in Cambodia were estimated at 15.9-18.5 $\mathrm{TgCO}_{2}$ depending on chosen scenario. With a carbon price of $\$ 5 \mathrm{MgCO}^{-1}$, total revenues from the sales of carbon credits alone are $\$ 79.5-92.5$ million annually. To ensure continued flow of wood supply from tropical forests while mitigating climate change, we suggest that new climate agreements adopt RIL or RIL+ for sustainable forest management in tropical countries.
\end{abstract}

Keywords: carbon credits; forest inventory; liberation treatment; reduced impact logging; timber concession; wood supply

\section{Introduction}

Negotiations for new climate agreements will be held at the $17^{\text {th }}$ Conference of the Parties (COP17) of the United Nations Framework Convention on Climate Change (UNFCCC) in Durban, South Africa in December 2011. Among the expected agreements are the financial incentives for mitigating climate change through the reduced emissions from deforestation and forest degradation, improving forest conservation and sustainable forest management, and enhancing carbon sinks or the "REDD+" scheme. REDD+ is an attractive option because it is less expensive $[1 ; 2 ; 3]$ than other options being taken under the Kyoto Protocol. In addition, it contributes directly to improving the livelihood of forest-dependent communities and therefore helps to achieve sustainable development of poor nations, while still contributing to mitigating global climate change $[4 ; 5]$. The anticipated REDD+ agreements have also attracted increasing research to estimate the carbon emission reductions and the associated costs of implementing the specified management activities, and how such emission reductions can be monitored and verified. Recent data suggest that between 2000 and 2009 , land use change (mostly tropical deforestation) was responsible for the release of $1.1 \pm 0.7 \mathrm{PgC}$ (about 4 billion tonnes $\mathrm{CO}_{2}$ ) [6]. Kindermann et al. [1] suggest that $50 \%$ of carbon emissions from tropical deforestation could be halted at carbon prices of $\$ 5.20-38.15$ per $\mathrm{MgCO}_{2}$ (tonne $\mathrm{CO}_{2}$ ) varying by continents. Sasaki and Yoshimoto [2] focused on the opportunity costs of managing tropical forests versus clearing these forests to develop industrial plantations, and suggested that managing tropical 
forests for timber production under the REDD+ mechanism would be preferable because of the huge potential revenues and other benefits from the ecosystem services provided by these forests. Toni [7] suggests the need for REDD+ decentralization in order to effectively manage the revenues from REDD+ scheme while protecting tropical forests. Although previous studies clarified the fundamental basis for understanding the potential of REDD+, many of them failed to address the potential reductions in carbon emissions and the timber supply from sustainably managing concession forests. Estimating emission reduction potentials require the understanding of the Reference Emission Level (REL: emissions in the absence of project activities) and the Project Emission Level (PEL: emissions from project implementation) [8].

Sustainable forest management (SFM) is an important part of REDD+, because it maintains wood supply from the forests to meet increasing demands for wood while generating employment and revenues for owners of the forest resource or for governments in developing countries. SFM is strongly affected by logging practices $[9 ; 10 ; 11]$, and logging practices are generally carried out by logging companies or concessionaire in the tropics. In fact, the majority of logging practices in the tropics are carried out under the forest concession system. If SFM is finally included in the REDD+ scheme under the new climate change agreements, a sound management system is required for managing concessions because the current logging practices were responsible for rapid forest degradation and deforestation [9; 12]. Furthermore, logging practices strongly influence the end-use wood supply and carbon stocks in concession forests in the tropics [13;14; 15], it is therefore necessary to understand which logging systems are both sustainable and economical. To better inform the policy makers as well as negotiators of the REDD+ scheme, there is critical need for developing methods for estimating the REL and PEL. So far until recently, there is no agreed-upon method for estimating REL or PEL [16], especially for REDD+ projects leading to reducing forest degradation and/or enhancing carbon sinks in concession forests where commercial logging for hard currency earnings is being practiced. Aiming at proposing appropriate system for managing tropical forests under the anticipated REDD+ scheme, we analyze and the potentials of carbon emission reductions from managing concession forests while achieving perpetual supply of end-use wood product from concession forests in Cambodia.

\section{Study Methods}

\subsection{Concession forests}

Natural forests in the tropical are commonly managed under forest concession system, a system that government as forest resource owner issues logging license to logging companies i.e. forest concessionaire to harvest the timber as per guidelines and laws of the countries in concerns. In 2006, Cambodia has a total forest cover of 10.7 million ha or about $59.1 \%$ of the country's total land area [17]. Deforestation rate was estimated at about $0.7 \%$ between 1973 and 2003 [14], and about $0.8 \%$ between 2002 and 2006 [17] (FA 2008). There are three major forest types in Cambodia namely evergreen, semi-evergreen, and deciduous forests. Other forest types include inundated and mangrove forests, and forest plantations but they represent only a small proportion of the total forest cover. Evergreen, semi-evergreen, and deciduous forests annually lost about $0.35 \%, 1.59 \%$, and $0.73 \%$, respectively between 2002 and 2006. Of the 10.7 million ha, concession, protection, and conversion forests account for $36.1 \%, 43.1 \%$, and $20.8 \%$, respectively. The 3.4 million ha of concession forests are under the jurisdiction of Forestry Administration of the Ministry of Agriculture, Forestry, and Fisheries (MAFF). Prior to logging ban in early 2002, a 25-year selective cutting cycle was used for managing concession forests in Cambodia. We therefore use 25-year cutting cycle as our business-as-usual cutting cycle.

\subsection{Management Scenarios}

Almost all logging practices in the tropics are carried out with less or without proper management plan and trained staff [18; 19]. Such logging is termed here as conventional logging (CVL). CVL refers to logging practices that require neither formal planning nor the use of trained staff. CVL causes large amounts of damage to the residual stand and wastes large amounts of wood both in the forest and at sawmill or pulp and paper plant [20]. In contrast, RIL and RIL+ scenarios are referred to management scenario using reduced-impact logging (RIL) and RIL+ (plus), which includes RIL and a "liberation" treatment. RIL is a logging practice that involves proper training of the logging staff; well-definded 
logging plans; careful planning of main, secondary, and feeder road locations before harvesting and extraction; the use of directional felling; cutting stumps low to the ground; minimizing wood waste caused by felling, skidding, and road transportation; minimizing road and trail widths; minimizing landing size and maximizing landing spacing; minimizing ground disturbance; paying attention to forest aesthetics; and minimizing damage to the residual stand. Sasaki and Putz [11] and Holmes et al. [20] provide more details about RIL practices. RIL is a promising logging practice for managing tropical forests [18], because it involves careful planning to minimize waste and adverse impacts on the residual stand. RIL+ is mostly the same as RIL, but also uses a liberation silvicultural treatment, in which unwanted trees that are competing with future crop trees are girdled to kill them. By reducing the competition from unwanted trees, growth rates of the crop trees can be increased by $20 \%$ to $60 \%$ compared with the growth rate in forests where only RIL is implemented [21;22].

\subsection{Carbon Stock Changes}

We describe the changes in the aboveground carbon stocks per hectare in tropical forest under the CVL, RIL, and RIL+ approaches using the following modified equations of Kim Phat et al. [13]:

$$
\begin{aligned}
& \frac{\mathrm{dCS}_{\mathrm{i}}(\mathrm{t})}{\mathrm{dt}}=\text { MAI }-\left[\mathrm{LM}_{\mathrm{i}}(\mathrm{t})-\mathrm{H}_{\mathrm{i}}(\mathrm{t})\right] \times \mathrm{BEF} \\
& \mathrm{H}_{\mathrm{i}}(\mathrm{t})=\frac{\mathrm{f}_{\mathrm{M}} \times \mathrm{f}_{\mathrm{H}}}{1-\mathrm{r}} \times \frac{\mathrm{CS}_{\mathrm{i}}(\mathrm{t})}{\mathrm{T}_{\mathrm{c}} \times \mathrm{BEF}}
\end{aligned}
$$

where:

$\mathrm{CS}_{\mathrm{i}}(\mathrm{t})$ : aboveground carbon stock $\left(\mathrm{MgC} \mathrm{ha}^{-1}\right.$ ) under logging system $i$ (where $i$ is $\mathrm{CVL}$, RIL, or RIL+) in year $t$. It is assumed that forest management starts in 2010, and therefore $t_{0}$ is corresponding to 2010, the start of the simulation

MAl: mean annual increment $\left(\mathrm{MgC} \mathrm{ha}^{-1}\right.$ year $\left.^{-1}\right)$

$\left.\mathrm{LM}_{\mathrm{i}} \mathrm{t}\right)$ : carbon in dead trees lost due to logging-induced mortality $\left(\mathrm{Mg} \mathrm{C} \mathrm{ha}^{-1}\right.$ year $\left.^{-1}\right)$

$\mathrm{H}_{\mathrm{i}}(\mathrm{t})$ : harvested carbon $\left(\mathrm{Mg} \mathrm{C}_{\mathrm{C}} \mathrm{ha}^{-1}\right.$ year $\left.^{-1}\right)$

BEF: biomass expansion factor (ratio of total aboveground biomass to stem biomass)

$f_{M}$ : proportion of mature trees

$f_{H}$ : legal rate of harvesting permitted by the government

r: rate of illegal logging

$\mathrm{T}_{\mathrm{c}}$ : cutting cycle (years). To determine an appropriate logging cycle for managing concession forests in Cambodia, four cutting cycles, namely 25 years (previously adopted cycle), 40 years, 50 years, and 60 years.

Table 1. Summarizes the values of these parameters, the underlying assumptions, and the

\begin{tabular}{|c|c|c|c|c|}
\hline Description & CVL & RIL & RIL+ & Sources \\
\hline $\operatorname{CS}(0)$ & $\begin{array}{r}134.0 \\
1\end{array}$ & $\begin{array}{r}134.0 \\
1\end{array}$ & 134.01 & $\begin{array}{l}\text { Average from Kao and lida [23], Kim Phat et al. [24], } \\
\text { Sist and Saridan [25], Chave et al. [26], Wellhöfer } \\
\text { [27], and Nascimentoa and Laurance [28] }\end{array}$ \\
\hline$f_{M}$ & 0.50 & 0.50 & 0.50 & Kim Phat et al. [13] \\
\hline$f_{H}$ & 0.30 & 0.30 & 0.30 & Kim Phat et al. [13] \\
\hline r & 0.50 & \multicolumn{2}{|c|}{$\begin{array}{l}\text { not applicable as } \\
\text { explained in } \\
\text { equation (12) }\end{array}$} & Assumed based on Kim Phat et al. [13] \\
\hline Tc & 25 & 25 & 25 & $\begin{array}{l}\text { Practiced in Cambodia until logging was banned in } \\
2002\end{array}$ \\
\hline $\begin{array}{l}\text { MAl } \\
\text { (Mean } \\
\text { Annual } \\
\text { Increment) }\end{array}$ & 0.66 & 0.66 & $0.99^{1)}$ & $\begin{array}{l}\text { Elsewhere in tropics } 0.64 \text { reported in Lewis et al. [29] } \\
\text { and } 0.72 \text { reported in Phillips et al. [30] } \\
\text { 1): assumed } 50 \% \text { increase in MAl based on Peña- } \\
\text { Claros et al. [21] and Villegas et al. [22] }\end{array}$ \\
\hline
\end{tabular}
sources of these data. 


\begin{tabular}{|c|c|c|c|c|}
\hline BEF & 1.74 & 1.74 & 1.74 & Brown [31] \\
\hline$\alpha$ & $1.0^{2)}$ & $0.5^{3)}$ & $0.5^{3)}$ & $\begin{array}{l}\text { proportion of } \mathrm{H}(\mathrm{t}) \\
\text { 2): see Kim Phat et al. [13] for more explanation } \\
\text { 3): based on Chheng [32] }\end{array}$ \\
\hline s (WAS) & 0.30 & 0.10 & 0.10 & $\begin{array}{l}30 \% \text { waste for CVL, and } 10 \% \text { for RIL. See Kim Phat } \\
\text { et al. [12] for details }\end{array}$ \\
\hline
\end{tabular}

Wood waste due to processing

a (EWAS) $\quad 0.50 \quad 0.40 \quad 0.40 \quad 50 \%$ waste for CVL, $40 \%$ for RIL (see Kim et al. [33])

\subsection{Wood Products Model}

Under both logging systems, we calculated the quantities of the following wood components: wood products (WP), wood waste (WAS), logging mortality (LM), end-use wood products (EWP), and enduse wood waste at sawmill or pulp and paper mill (EWAS). To do so, we used the following equations:

$$
\begin{aligned}
& \mathrm{WP}_{\mathrm{i}}(\mathrm{t})=\left(1-\mathrm{s}_{\mathrm{i}}\right) \times \mathrm{H}_{\mathrm{i}}(\mathrm{t}) \\
& \mathrm{WAS}_{\mathrm{i}}(\mathrm{t})=\mathrm{H}_{\mathrm{i}}(\mathrm{t})-\mathrm{WP}_{\mathrm{i}}(\mathrm{t}) \\
& \mathrm{LM}_{\mathrm{i}}(\mathrm{t})=\alpha \times \mathrm{H}_{\mathrm{i}}(\mathrm{t}) \\
& \operatorname{EWP}_{\mathrm{i}}(\mathrm{t})=\left(1-\mathrm{a}_{\mathrm{i}}\right) \times \mathrm{WP}_{\mathrm{i}}(\mathrm{t}) \\
& \operatorname{EWAS}_{\mathrm{i}}(\mathrm{t})=\mathrm{WP}_{\mathrm{i}}(\mathrm{t})-\mathrm{EWP}_{\mathrm{i}}(\mathrm{t})
\end{aligned}
$$

where:

$s_{i}$ : proportion of unusable wood after deducting losses due to logging, skidding, and damage during transportation under system $i(\mathrm{CVL}, \mathrm{RIL}$, or RIL+)

a: proportion of trees killed by logging, log skidding

$a_{i}$ : wood processing efficiency (wood recovery) under system $i$

The units of WP, WAS, LM, EWP, and EWAS are Mg C ha $\mathrm{year}^{-1}$, otherwise stated

\subsection{Maintaining the End-use Wood Supply}

Sustainable forest management cannot be achieved if maintaining a long-term sustainable wood supply is not part of the management goals. In this analysis, we assumed that the EWP produced under the CVL system is a baseline against which the EWPs from RIL and RIL+ are compared. Therefore, the EWPs from both logging practices must be equal:

$$
\begin{aligned}
& \operatorname{EWP}_{\mathrm{CVL}}(\mathrm{t})=\left(1-\mathrm{a}_{\mathrm{CVL}}\right) \times \mathrm{WP}_{\mathrm{CVL}}(\mathrm{t}) \\
& \mathrm{EWP}_{\mathrm{R}}(\mathrm{t})=\left(1-\mathrm{a}_{\mathrm{R}}\right) \times \mathrm{WP}_{\mathrm{R}}(\mathrm{t})
\end{aligned}
$$

where the subscript "R" means that the equation can be used for both RIL and RIL+." 
To maintain a long-term wood supply under the REDD+ scenario (using RIL or RIL+) that is comparable to that under the baseline scenario (using CVL), the wood supply under CVL must be maintained:

$$
\operatorname{EWP}_{\mathrm{R}}(\mathrm{t})=\mathrm{EWP}_{\mathrm{CVL}}(\mathrm{t})
$$

or

$$
H_{R}(t)=\frac{\left(1-a_{C V L}\right)\left(1-s_{C V L}\right)}{\left(1-a_{R}\right)\left(1-s_{R}\right)} \times H_{C V L}(t)
$$

This study only includes aboveground carbon stocks. Belowground carbon and carbon fluxes in various harvested wood products are not accounted for.

\subsection{Reference Emission Level, Project Emission Level, and Carbon Crediting}

Crediting reduced carbon emissions (carbon credits hereafter or $C C$ ) requires the understanding of at least three important variables. They are Reference Emission Level (REL) or baseline emissions or emissions in the absence of project activities, Project Emission Level (PEL) or emissions resulted from implementing the projects, and Leakages $(L)$ or the emissions outside the project boundaries. Until recently, there is agreed-upon formula for determining the REL, PEL or $L$ [16]. As REDD+ scheme of the UNFCCC is a performance-based compensation for reduced carbon emissions or sinks resulted from implementing project activities, here we developed equations for estimating carbon credits (CC) from project implementation in concession forests in the tropics. CC can be derived by:

$$
\begin{aligned}
& \mathrm{CC}(\mathrm{t})=\operatorname{REL}(\mathrm{t})-\operatorname{PEL}(\mathrm{t})-\mathrm{L}(\mathrm{t})-\mathrm{EP}(\mathrm{t}) \\
& \operatorname{REL}(\mathrm{t})=\left[\mathrm{CS}_{\mathrm{CVL}}(\mathrm{t})-\mathrm{CS}_{\mathrm{CVL}}(\mathrm{t}-1)\right] \times 3.67 \\
& \operatorname{PEL}(\mathrm{t})=\left[\mathrm{CS}_{\mathrm{RIL}}(\mathrm{t})-\mathrm{CS}_{\mathrm{RIL}}(\mathrm{t}-1)\right] \times 3.67 \\
& \operatorname{PEL}(\mathrm{t})=\left[\mathrm{CS}_{\mathrm{RIL}+}(\mathrm{t})-\mathrm{CS}_{\mathrm{RIL}+}(\mathrm{t}-1)\right] \times 3.67
\end{aligned}
$$

where:

$\mathrm{REL}(\mathrm{t})$ : Reference emission level at year $t\left(\mathrm{TgCO}_{2}\right.$ year $\left.{ }^{-1}\right)$. Emissions under the conventional logging $(C V L)$ scenario is taken as baseline emissions

PEL(t): Project emission level at year $t\left(\mathrm{TgCO}_{2}\right.$ year $\left.^{-1}\right)$

$\mathrm{L}(\mathrm{t})$ : Leakages or carbon emissions outside project boundary $\left(\mathrm{TgCO}_{2}\right.$ year $\left.{ }^{-1}\right)$. $\mathrm{L}$ in forestry project is difficult to estimate but Murray et al. [34] found that $L$ varies greatly from one location to another. For simplicity, $30 \%$ is assumed for $L$ for our study.

EP(t): Emissions from project's fieldwork activities such as emissions from logging operations and wood transportation. According to UNFCCC [35], emissions that account for $10 \%$ or less of the overall emissions can be excluded in the calculation. Therefore, we excluded EP in our CC calculation because it is unlikely that EP is more than $10 \%$ of the overall emissions

$\mathrm{CS}_{\mathrm{CVL}}(\mathrm{t}), \mathrm{CS}_{\mathrm{RIL}}(\mathrm{t}), \mathrm{CS}_{\mathrm{RIL}+}(\mathrm{t})$ : Carbon stocks in the year $t$ under $\mathrm{CVL}$, RIL, and $\mathrm{RIL}+$ scenarios, respectively $(\mathrm{TgC})$

$3.67=44 / 12$ : is the ratio of the molecular weight of $\mathrm{CO} 2(44)$ to the molecular weight of carbon

If $P E L=0$, the project neither generate carbon sinks nor source. If $P E L(t)<0$, the project generates sinks resulted from the applications of RIL or RIL+ because RIL or RIL+ is able to reduce harvested wood thereby reducing damages to residual stands while RIL or RIL+ still maintains the wood supply equivalent to that under the business as usual scenario, e.g. under the conventional logging. If $\mathrm{PEL}(\mathrm{t})>0$, the project generates sources. But, as long as $\mathrm{PEL}(\mathrm{t})<\mathrm{REL}(\mathrm{t})$, "additionality" or "carbon credits" can still be achieved. 
2.7. Wood Products and Overall Carbon Stocks

Total wood products and carbon stocks for each scenario from managing 3.4 million ha of concession forests in Cambodia are the products of respective variables with area of concession forests.

\section{Results and Discussions}

\subsection{End-use Wood Products and Wood Wastes}

Regardless the source of end-use wood product and due to the lack of information on actual timber demand and supply in Cambodia, our study assumed that the demand of end-use wood products is equivalent to that produced under the conventional logging scenario (Equation 10). This supply is maintained under the RIL and RIL+ scenarios. Under the current cutting cycle of 25 years for all three management scenarios, managing 3.4 million ha of concession forests in Cambodia produces, on average, 3.1 million $\mathrm{m}^{3}$ of the annual end-use wood product at a declining rate of $1.8 \%$ annually over the entire 25-year period (Figure 1). In terms of wood wastes (onsite and at the sawmill), CVL creates 5.8 million $\mathrm{m}^{3}$ year ${ }^{-1}$ over the same period while only 2.6 million $\mathrm{m}^{3}$ year ${ }^{-1}$ of wastes are created under the RIL (including RIL and RIL+) or about $100.5 \%$ less than that created by CVL. CVL produces wastes $218 \%$ higher than that produced under the RIL and RIL+ scenarios. Wood wastes under CVL result from huge wood wastes caused by unprofessional logging, log skidding, trimming and transporting, and wastes at sawmill.

Illegal logging strongly influences the end-use wood products and carbon stocks in the forests. If half of the wood from illegal logging is eliminated ( $r=0.5 / 2)$, wood supply is maintained at 2.3 million $\mathrm{m}^{3}$ year ${ }^{-1}$ but declining rate is at about $1.0 \%$. If illegal logging is completely eliminated $(r=0)$, wood supply is maintained at 1.8 million $\mathrm{m}^{3}$ year ${ }^{-1}$ but declining rate is at only about $0.7 \%$. Our estimates are well within wood production estimated the World Bank et al. [36] and DAI [37] whose annual wood production (including illegal production) was reported at 1.5-4.3 million $\mathrm{m}^{3}$ from 1995 to 1997.

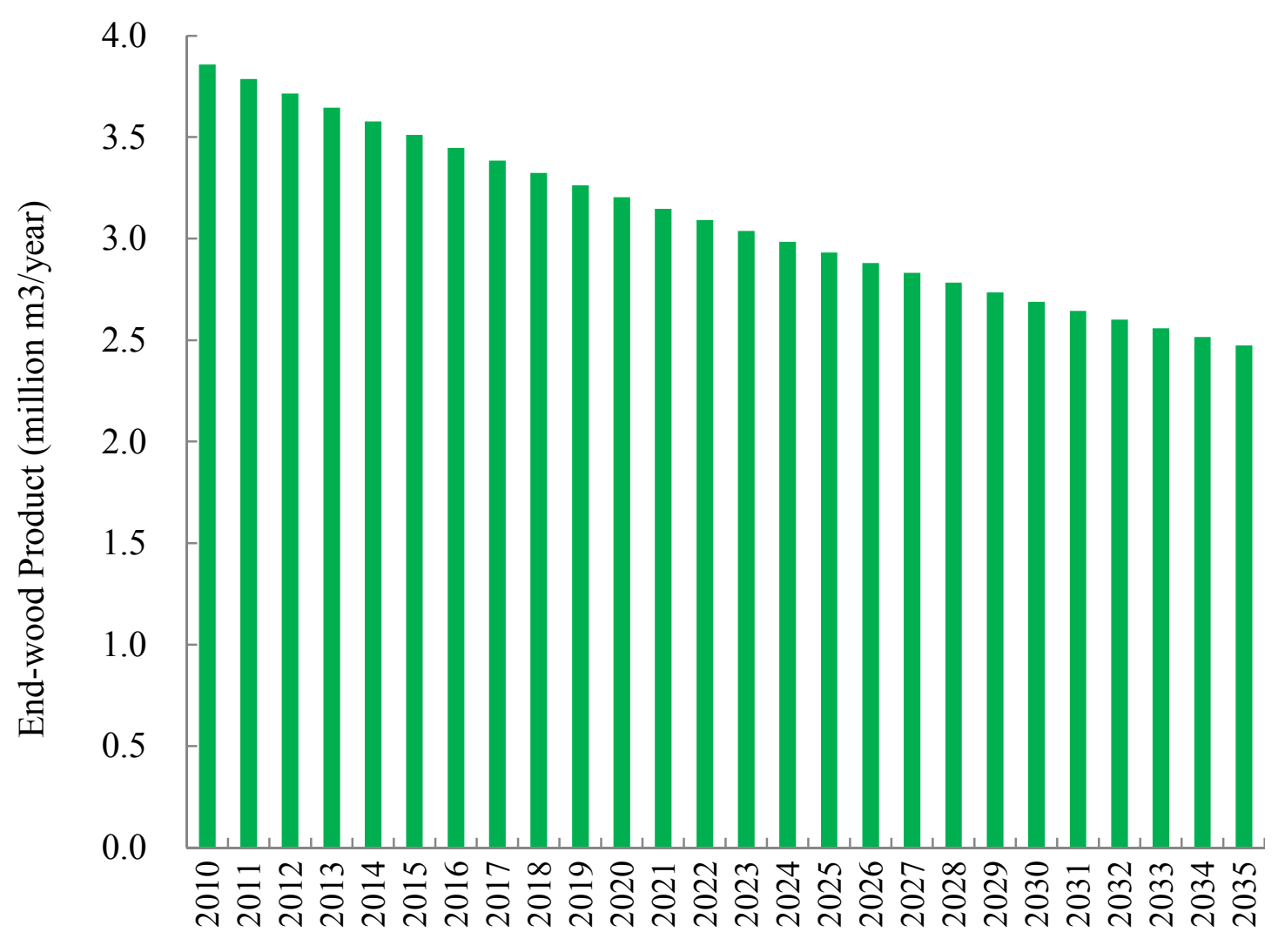

Timeframe (year)

Figure 1. Annual end-use wood products under three management scenarios over a 25-year period 


\subsection{Carbon Stock Changes}

Our models suggest that under the conventional logging, total carbon stocks in 3.4 million ha of concession forests decrease to $292.2 \mathrm{Tg} \mathrm{C}$ at the year $25^{\text {th }}$ (the end of the cutting cycle, $\mathrm{t}=25$ ) from 455.6 at the start of the management $(\mathrm{t}=0)$, representing an annual degradation (emissions) of 6.5 $\mathrm{TgC}$ or $23.9 \mathrm{Tg} \mathrm{CO}_{2}\left(1 \mathrm{Tg} \mathrm{CO}=1\right.$ million tonnes $\left.\mathrm{CO}_{2}\right)$ or $1.4 \%$ annually. Respectively under the RIL and RIL+, carbon stocks also decrease to 403.4 and $428.2 \mathrm{Tg} \mathrm{C}$ at $\mathrm{t}=25$ from $455.6 \mathrm{Tg} \mathrm{C}$ and 455.6 $\mathrm{Tg} \mathrm{C}$ at $\mathrm{t}=0$, representing an annual degradation of $14.7 \mathrm{Tg} \mathrm{CO}_{2} \quad(0.9 \%)$ and $11.4 \mathrm{TgCO}_{2}(0.5 \%)$ over a 25-year cutting cycle (Figure 2).

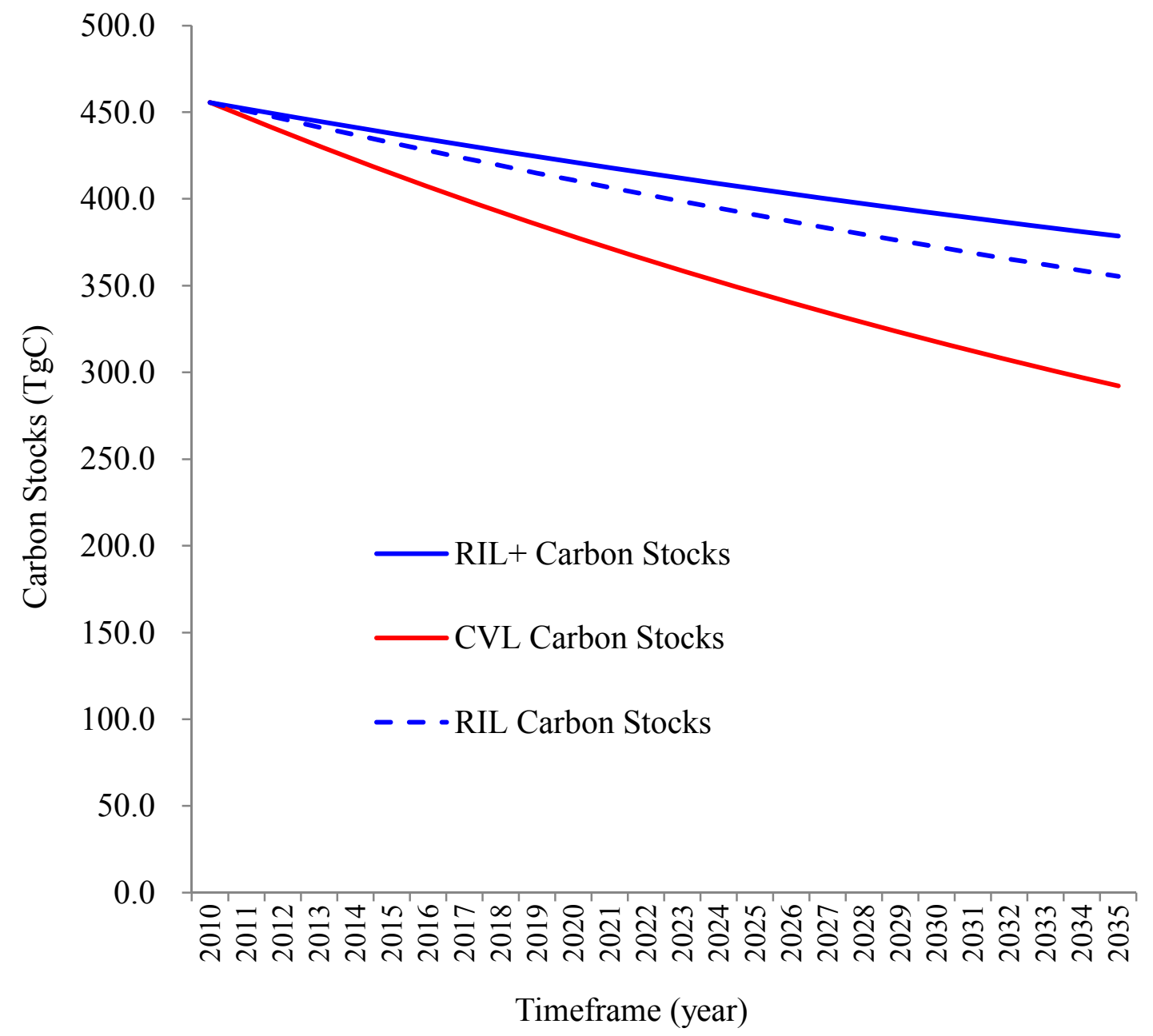

Figure 2. Carbon stocks under the three management scenarios over a 25 -year cutting cycle

Illegal logging also strongly affects carbon stocks in the forests. If half of the rate of illegal logging used in our study is halted, annual carbon loss (degradation) is $15.3 \mathrm{Tg} \mathrm{CO}_{2}, 8.0 \mathrm{Tg} \mathrm{CO}$, and $4.4 \mathrm{Tg}$ $\mathrm{CO}_{2}$ under $\mathrm{CVL}$, RIL, and RIL+ scenarios, respectively. If illegal logging is completely eliminated, managing concession forests under the CVL, RIL, and RIL+ scenario results in annual carbon loss (degradation) of $10.2,4.3$, and $0.6 \mathrm{Tg} \mathrm{CO}_{2}$, respectively over the 25-year cutting cycle (Figure 3). 


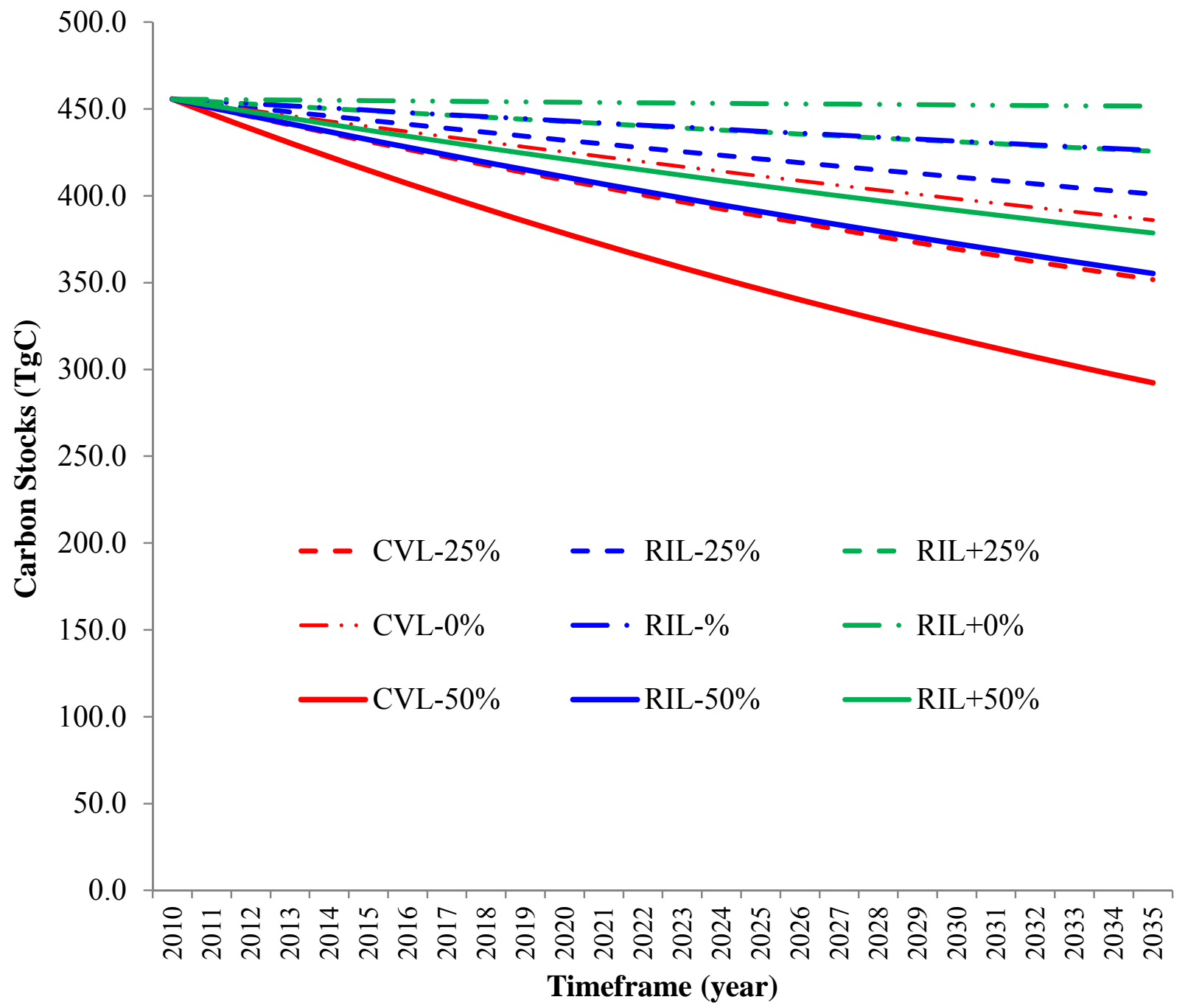

Note:

Figure 3. Carbon stock changes affected by illegal logging

CVL-50\%, CVL-25\%, and CVL-0\% are carbon stock changes

Because previous study on avoided emissions from forest degradation through managing concession forests was very limited, it is difficult to compare our carbon emission reductions with that of previous studies. Asner et al. [12; 38] found that at least $20 \%$ of tropical forests were under various forms of selectively logging, and forest degradation in Amazon doubled during the 2000s. Conventional logging also caused rapid deforestation in Amazon, where selectively logged forests were cleared in 4 years after logging [9] suggesting that large amount of timber volume was harvested and degraded.

\subsection{Appropriate Management System}

In order to determine the appropriate management system in terms of maintaining the sustainable supply of end-use wood products from managing concession forests in Cambodia, three more cutting cycles were tested under the three management scenarios with three rates of illegal logging, namely the $50 \%$ rate (upper left on Figure 4), $25 \%$ rate (upper right on Figure 4), and zero (lower part of figure 4). The testing results (Figure 4) indicate that the annual end-use wood product from 3.4 million ha of concession forests is about 1.08 million $\mathrm{m}^{3}$, increasing $0.06 \%$ annually under the 60 -year cutting cycle and if illegal logging is reduced to $25 \%$ (Table 2). If illegal logging is completely eliminated, a 40 -year cutting cycle would be appropriate and it could ensure the sustainable supply of end-use wood product of 1.21 million $\mathrm{m}^{3}$ under the RIL or RIL+ practices. Given the nature of illegal logging and governance problems in developing countries, it is unlikely that illegal logging can be completely eliminated. Taking into account the need for investment return, a cutting cycle of between 40 and 60 
years would be appropriate. Cutting cycles that are shorter than 40 years can not ensure the longterm sustainable supply of end-use product. The testing results also suggest that short cutting cycles coupled with illegal logging produce high production of end-use wood but on a sharply decline basis as shown in Figure 4. Countries with instable political situation are likely to adopt the short cutting cycles for immediate financial gains in the expense of forest resources and carbon stocks. Such practices were actually behind the rapid forest degradation and deforestation in the tropics in the last several decades [39].
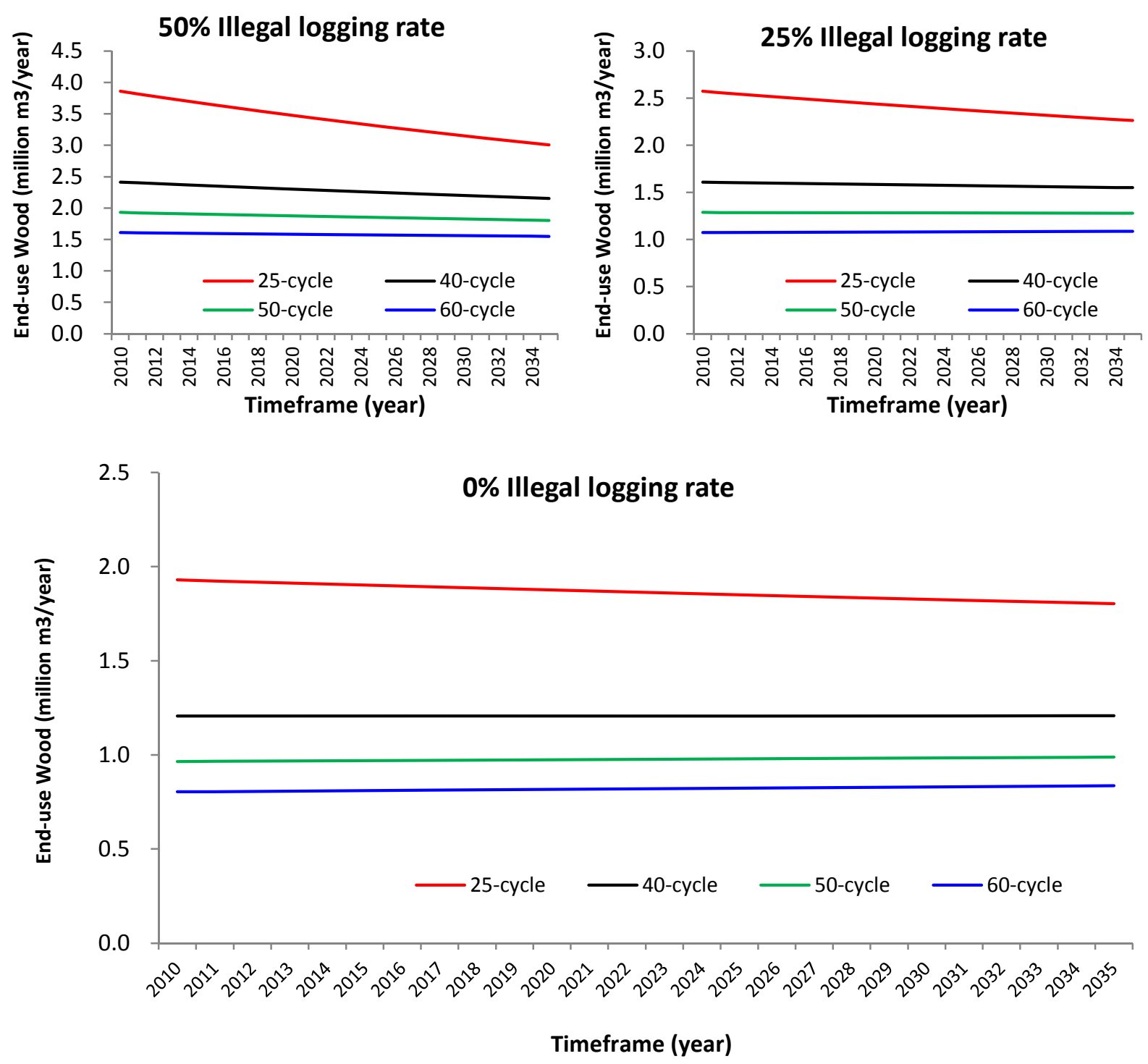

Figure 4. Supply of end-use wood products under four cutting cycles with and without illegal logging

Table 2. Average annual end-use wood product under 4 cutting cycles and 3 rates of illegal logging

\begin{tabular}{lcccccc}
\hline \multirow{2}{*}{$\begin{array}{l}\text { Cutting } \\
\text { Cycle }\end{array}$} & \multicolumn{2}{c}{ Illegal logging rate: $50 \%$} & \multicolumn{2}{c}{ Illegal logging rate: $25 \%$} & \multicolumn{2}{c}{ Illegal logging rate: 0\% } \\
\cline { 2 - 7 } (million $\left.\mathrm{m}^{3}\right)$ & $(\%)$ & $\left(\right.$ million $\left.\mathrm{m}^{3}\right)$ & $(\%)$ & $\left(\right.$ million $\left.\mathrm{m}^{3}\right)$ & $(\%)$ \\
\hline 25-year cycle & 3.41 & $-0.88 \%$ & 2.41 & $-0.48 \%$ & 1.86 & $-0.26 \%$ \\
40-year cycle & 2.28 & $-0.43 \%$ & 1.58 & $-0.15 \%$ & $\mathbf{1 . 2 1}$ & $\mathbf{0 . 0 0 \%}$ \\
50 -year cycle & 1.86 & $-0.26 \%$ & 1.28 & $-0.03 \%$ & $\mathbf{0 . 9 8}$ & $\mathbf{0 . 1 0 \%}$ \\
60-year cycle & 1.58 & $-0.15 \%$ & $\mathbf{1 . 0 8}$ & $\mathbf{0 . 0 6 \%}$ & $\mathbf{0 . 8 2}$ & $\mathbf{0 . 1 6 \%}$ \\
\hline
\end{tabular}

Note: Values in this table are the average for 25-year modeling timeframe 
Taking into account the past experience with illegal logging and governance and the inability to completely reduce illegal logging, a 50 -year cutting cycle with $25 \%$ rate of illegal logging is more realistic, and therefore appropriate for managing forests under the REDD+ scheme.

Liberation treatment should be used with pre-caution since only two experiments have been done so far (Peña-Claros et al. [21] and Villegas et al. [22]). This practice should be carefully practiced by well-trained professionals who have knowledge about tree species and their interactions with other organisms in the forests. Otherwise, only highly commercial tree species will be left to grow in expense of other species and tree-dependent biodiversity.

\subsection{Reference Emission Level, Project Emission Level, and Carbon Credits}

By taking 50-year cutting cycle is a management system for REDD+ scheme, REL, PEL and carbon credits can be determined. Assumed that the first carbon crediting period is 25 years (half of the cutting cycle) and if the 50-year cutting cycle is adopted for REDD+ project in Cambodia and the project is able to reduce the current rate of illegal logging to $25 \%$, carbon stocks under CVL, $\mathrm{RIL}$, and RIL+ scenarios are 455.6 Tg C at the beginning of the management $(t=0)$ and 423.9, 452.9, and 479.2 $\mathrm{Tg} \mathrm{C}$, and $499.5 \mathrm{Tg} \mathrm{C}$ at the year $25^{\text {th }}$ (end of first crediting period), respectively declining $1.3 \mathrm{TgC}(0.3 \%), 0.1 \mathrm{TgC}(0 \%)$, and $-0.9 \mathrm{TgC}(-0.2 \%)$ (Figure 5$)$. By conventional way of writing, minus '-' refers to carbon sinks.

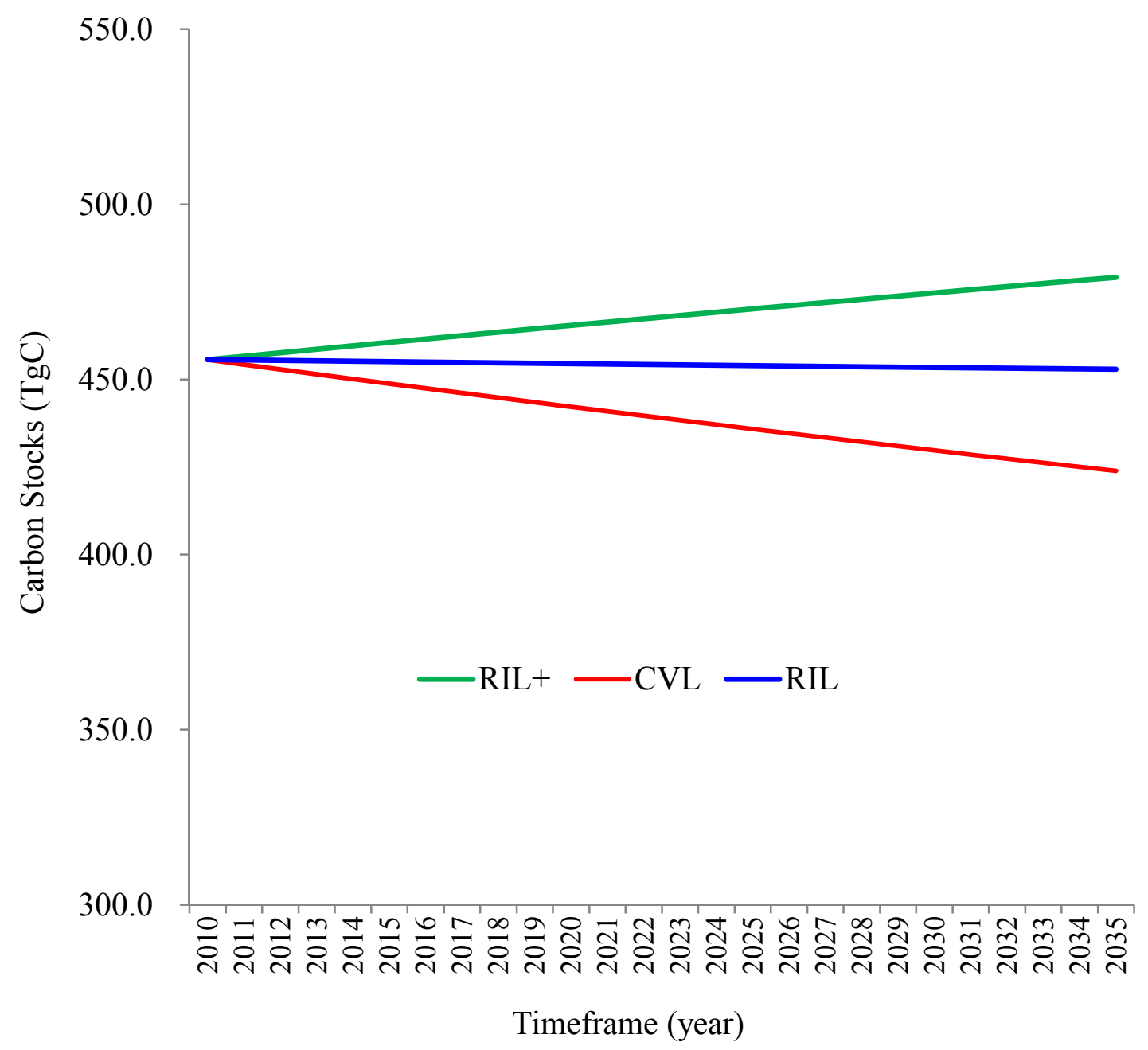

Figure 5. Carbon stocks under a 50-year cutting cycle without $25 \%$ rate of illegal logging in concession forests in Cambodia in the first crediting period 
With the above assumptions (25-year carbon crediting period, 50 -year cutting cycle, $25 \%$ rate of illegal logging), two types of REL can be argued, namely the REL under the current conventional logging practice of 25-year cutting cycle and the REL under the conventional logging practice of 50 -year cutting cycle. REL under the latter is unlikely because it is a proposed practice for RIL or $\mathrm{RIL}+$ system that would be adopted for future REDD+ projects in concession forests [2]. It is therefore REL under the conventional logging of the 25-year cutting cycle is chosen for comparison in our study. REL and PEL were estimated at zero at beginning of the project $(t=0)$. At the second year of the project implementation, REL increased to $31.5 \mathrm{TgCO}_{2}$, then decreased to $17.7 \mathrm{TgCO}_{2}$ in year 25 of the project implementation. This decrease is caused by the decrease of available timber for harvesting. On average over the first crediting period, REL was estimated at $23.1 \mathrm{TgCO}_{2}$ year ${ }^{-1}$. On the other hands, PEL increased to $0.4 \mathrm{TgCO}_{2}$ and $-3.7 \mathrm{TgCO}_{2}$ at the second year, respectively under RIL and RIL+ scenarios. PEL remained constant at $0.4 \mathrm{TgCO}_{2}$ under RIL but slowly declined to $-3.2 \mathrm{TgCO}_{2}$ under RIL+ at the year $25^{\text {th }}$ of the project implementation (Figure 6). The minus, "-" sign refers to carbon sinks or enhanced carbon sinks in the REDD+ meaning. Average PELs were $0.4 \mathrm{TgCO}_{2}$ year $^{1}$ and $-3.3 \mathrm{TgCO}_{2}$ year ${ }^{1}$ under RIL and RIL+, respectively. After subtracting $30 \%$ from [REL(t)-PEL(t)], CC under the RIL or RIL+ was estimated at about 15.9 $\mathrm{TgCO}_{2}$ year ${ }^{1}$ or $18.5 \mathrm{TgCO}_{2}$ year ${ }^{1}$ under RIL and $\mathrm{RIL}+$ scenarios, respectively. If carbon is priced at $\$ 5$ (average carbon price at the voluntary carbon market was $\$ 7.88$ per MgCO2 ranging from $\$ 0.67$ to $\$ 50$ [40]), total annual carbon-based revenues from managing 3.4 million ha of concession forests were estimated at $\$ 79.5$ million under RIL to $\$ 92.5$ million. In addition to these carbon-based revenues, revenues from timber royalties and other benefits from long-term management of concession forests can also be obtained. The carbon-based revenues alone are more than 4 times higher than the timber revenues from logging in Cambodia reported in 1995 [33].

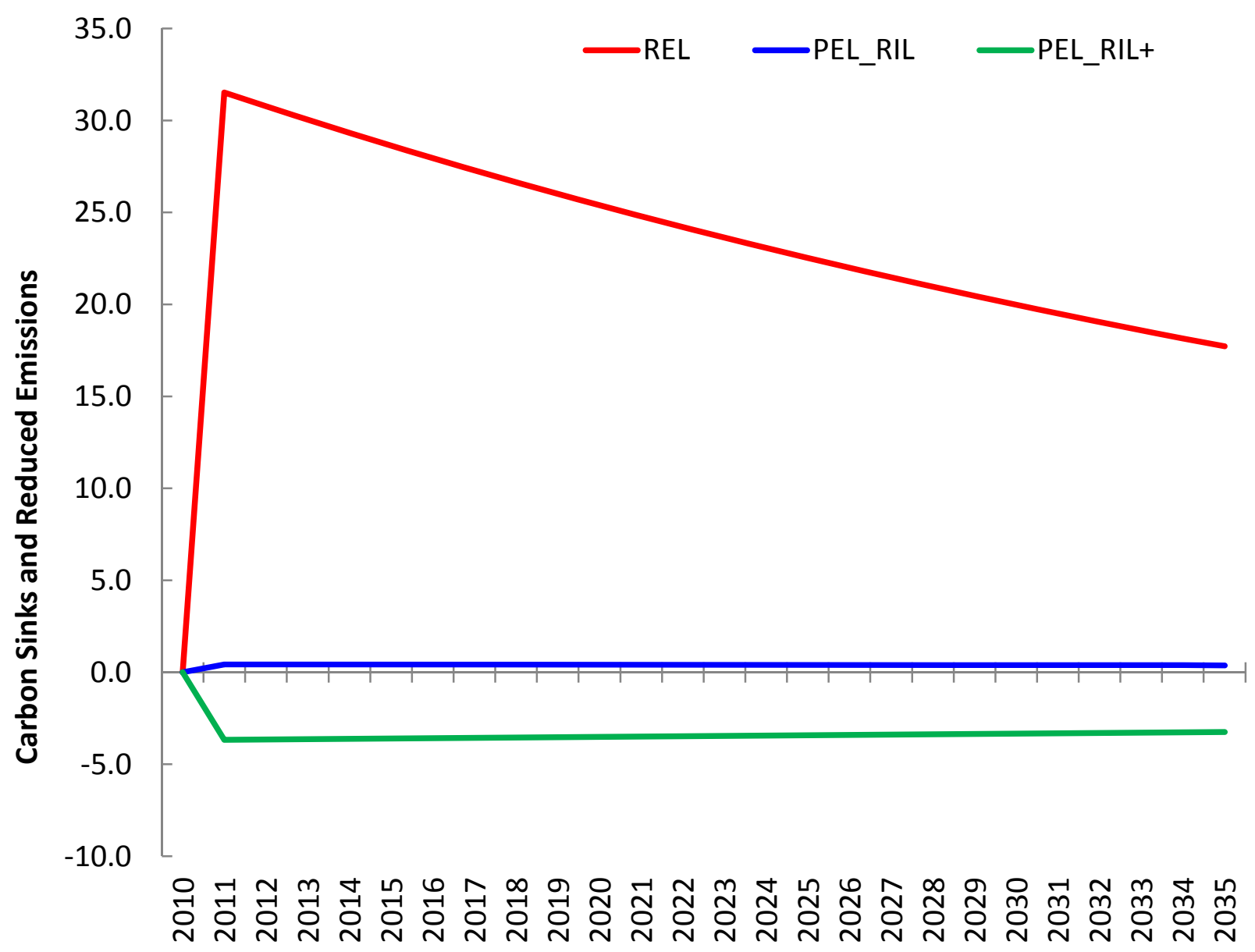

\section{Timeframe}

Figure 6. Reference emission level and enhanced carbon sinks 
Note: PEL_RIL and PEL_RIL+ are project emission levels under the RIL and RIL+ scenarios

Logging costs had been generally thought to be expensive under the RIL or RIL+ options but based on various studies in the tropics, Sasaki et al. [19] argued costs are not expensive as previously thought. However, cost-effective analysis is beyond the scope of this paper.

\section{Conclusions}

We developed methods to estimate REL, PEL, and carbon credits for REDD+ projects in tropical forests under three management scenarios, e.g. the management under conventional logging, reduced impact logging (RIL) and RIL with liberation treatment (RIL+). Carbon credits generated from the REDD+ projects are huge and would be attractive to project developers if there are continued financial incentives and/or carbon markets for such credits. The inclusion of the REDD+ scheme in the new reduction mechanisms for post-Kyoto project implementation will ensure such incentives and carbon market.

Our results suggest that a 25-year cutting cycle currently being practiced in Cambodia is too short to sustain the flow of end-use wood production. A 50-year cutting cycle under the reduced impact logging (RIL) or RIL with liberation treatment (RIL+) could maintain the perpetual supply of end-use wood product but at a smaller amount compared to that under conventional logging with short-term cutting cycle. Achieving sustainable forest management under the REDD+ mechanism will require the adoption of sound logging practices that will reduce damage to forest residual stands and the soils that sustain these stands, and that will therefore reduce disturbances to upstream resources (e.g., forests that protect catchment ecosystem services) while maintaining a perpetual flow of end-use wood products. Without carbon-based incentives such as carbon incentives under the REDD+ scheme, RIL+ would not be adopted and therefore emissions from logging can not be avoided putting efforts to mitigating climate change and achieving sustainable development in developing countries at risk.

Financing currently made available from the fast-start climate finance should also be used for capacity building on RIL or RIL+ for effective implementation when REDD+ scheme becomes an international binding agreements, under which RIL or RIL+ is required for managing tropical forests. For RIL+, pre-cautionary measures should be taken to prevent the killing of commercially less important but biologically important tree species.

\section{Acknowledgments}

This study was partially supported by a Grant-in-Aid for Scientific Research (No. 18402003) from the Ministry of Education, Culture, Sports, Science and Technology of Japan.

\section{References}

[1] Kindermann, G.; Obersteiner, M.; Sohngen, B.; Sathaye, J.; Andrasko, K.; Rametsteiner, E.; Schlamadinger, B.; Wunder, S.; Beach, R. Global cost estimates of reducing carbon emissions through avoided deforestation. Proc. Natl. Acad. Sci. USA. 2008, 105, 1030210307.

[2] Sasaki, N.; Yoshimoto, A. Benefits of tropical forest management under the new climate change agreement-a case study in Cambodia. Environ. Sci. Pol. 2010,13, 384-392.

[3] van Kooten, G.C.; Eagle, A.J.; Manley, J.; Smolak, T. How costly are carbon offsets? A metaanalysis of carbon forest sinks. Environ. Sci. Pol. 2004, 7, 239-251.

[4] Gullison, F.R.; Frumhoff, C.P.; Canadell, G.J.; Field, C.B.; Nepstad, D.C.; Hayhoe, K.; Avissar, R.; Curran, L.M.; Friedlingstein, P.; Jones, C.D.; Nobre, C. Tropical forests and climate policy. Science 2007, 136, 985-986.

[5] Houghton, R.A. Revised estimates of the annual net flux of carbon to the atmosphere from changes in land use and land management 1850-2000. Tellus 2003, 55B, 378-390.

[6] Friedlingstein, P.; Houghton, R. A.; Marland, G.; Hackler, J.; Boden, T. A.; Conway, T. J.; Canadell, J. G.; Raupach, M. R.; Ciais, P.; Le Quéré, C. Update on $\mathrm{CO}_{2}$ emissions. Nature Geoscience 2010, 3, 811-812.

[7] Toni, F. Decentralization and REDD+ in Brazil. Forests 2011, 2, 66-85. 
[8] Ty, S.; Sasaki, N.; Ahmad, A.H.; Zainal, A. Z. REDD development in Cambodia -potential carbon emission reductions in a REDD Project. FORMATH 2011, 10, 1-23.

[9] Asner, G. P.; Broadbent, E. N.; Oliveira, P. J.; Keller, M.; Knapp, D. E.; Silva, J. N. Condition and fate of logged forests in the Brazilian Amazon. Proc. Natl. Acad. Sci. USA. 2006, 103 12947-12950.

[10] Pearce, D.W.; Putz, E.F.; Vanclay, J.K. Sustainable forestry in the tropics: panacea or folly? Forest Ecol Manag. 2003, 172, 229-247.

[11] Sasaki, N.; Putz, F.E. Critical need for new definitions of forest and forest degradation in global climate change agreements. Conservation Letters 2009, 2, 226-232.

[12] Asner, G. P.; Powell, G. V. N.; Mascaro, J.; Knapp, D. E.; Clark, J. K.; Jacobson, J.; KennedyBowdoin, T.; Balaji, A.; Paez-Acosta, G.; Victoria, E.; Secada, L.; Valqui, M.; Hughes, R. F. High-resolution carbon stocks and emissions in the Amazon. Proc. Natl. Acad. Sci. USA. 2010, 107:16,738-16,742.

[13] Kim Phat, N.; Knorr, W.; Kim, S. Appropriate measures for conservation of terrestrial carbon stocks - analysis of trends of forest management in Southeast Asia. Forest Ecol Manag. 2004, 191, 283-299.

[14] Sasaki, N. Carbon emissions due to land-use change and logging in Cambodia- a modeling approach. Jpn. For Res 2006, 11, 397-403.

[15] Sist, P.; Sheil, D.; Kartawinata, K.; Priyadi H. Reduced-impact logging in Indonesian Borneo: some results confirming the need for new silvicultural prescriptions. Forest Ecol Manag. 2003, $179,415-427$

[16] Angelsen, A. (ed.) 2008 Moving ahead with REDD: Issues, options and implications. CIFOR, Bogor, Indonesia.

[17] FA (Forestry Administration). Forest Cover Statistics in Cambodia 2002-2006. FA, Phnom Penh, Cambodia 2008.

[18] Putz, F.E.; Zuidema, P.A.; Pinard, M. A.; Boot, R.G.A; Sayer, J.A.; Sheil, D.; Sist, P.; Vanclay, J.K. Improved tropical forest management for carbon retention. PLoS Biol 2008, 6, e166. doi:10.1371/journal.pbio.0060166

[19] Sasaki, N.; Asner, G.P.; Knorr, W.; Durst, P.B.; Priyadi, H.; Putz, F.E. Approaches to classifying and restoring degraded tropical forests for the anticipated REDD+ climate change mitigation mechanism. iForest - Biogeosciences and Forestry 2011, 4, 1-6.

[20] Holmes, T.P.; Blate, G.M.; Zweede, J.C.; Pereira, R.; Barreto, P.; Boltz, F.; Bauch, R. Financial and ecological indicators of reduced impact logging performance in the eastern Amazon. Forest Ecol Manag. 2002, 163(1-3), 93-110.

[21] Peña-Claros, M.; Fredericksen, T.S.; Alarcón, A.; Blate, G.M.; Choque, U.; Leaño, C.; Licona, J.C.; Mostacedo, B.; Pariona, W.; Villegas, Z.; Putz, F.E. Beyond reduced-impact logging: Silvicultural treatments to increase growth rates of tropical trees. Forest Ecol Manag. 2008, 256, 1458-1467.

[22] Villegas, Z.; Peña-Claros, M.; Mostacedo, B.; Alarcón, A.; Licona, J.C.; Leaño, C.; Pariona, W.; Choque, U. Silvicultural treatments enhance growth rates of future crop trees in a tropical dry forest. Forest Ecol Manag. 2009, 258, 971- 977.

[23] Kao, D.; lida, S. Structural characteristics of logged evergreen forests in Preah Vihear, Cambodia, 3 years after logging. Forest Ecol Manag. 2003, 225, 62-73.

[24] Kim Phat, N.; Ouk, S.; Uozumi, Y.; Ueki, T. Stand dynamics of Dipterocarp trees in Cambodia's evergreen forest and management implications- A case study in Sandan district, Kampong Thom. Jpn. Journal of Forest Planning 2000, 6, 13-23.

[25] Sist, P.; Saridan, A. Description of the Primary Lowland Forest of Berau. In: Silvicultural Research in a Lowland Mixed Dipterocarp Forest of East Kalimantan; Bertault, J.G., Kadir, K. Eds.: The Contribution of STREK Project. CIRADFORDA-P.T. INHUTANII, Indonesia 1998 pp. 51-94.

[26] Chave, J.; Andalo, C.; Brown, S.; Cairns, M. A.; Chambers, J. Q.; Eamus, D.; Folster, H.; Fromard, F.; Higuchi, N.; Kira, T.; Lescure, J-P; Nelson, B. W.; Ogawa, H.; Puig, H.; Rie'ra, B.; Yamakura, T. Tree allometry and improved estimation of carbon stocks and balance in tropical forests. Oecologia 2005, 145, 87-99 
[27] Wellhöfer S (2002). Environmentally Sound Forest Harvesting in Brazil - Assessment of Regeneration and Environmental Impacts four years after Harvesting. FAO Forest Harvesting Case Study 19. FAO, Rome.

[28] Nascimentoa, E.M.H.; Laurance, F.W. Total aboveground biomass in central Amazonian rainforests: a landscape-scale study. Forest Ecol Manag. 2002, 168, 311-321.

[29] Lewis, S.L.; Lopez-Gonzalez, G.; Sonké, B.; Affum-Baffoe, K.; Baker, T.R.; Ojo, L.O.; Phillips, O.L.; Reitsma, J.M.; White, L.; Comiskey, J.A.; Djuikouo, K.M.N.; Ewango, C.E.; Feldpausch, T.R.; Hamilton, A.C.; Gloor, M.; Hart, T.; Hladik, A.; Lloyd, J.; Lovett, J.C.; Makana, J.R.; Malhi, Y.; Mbago, F.M.; Ndangalasi, H.J.; Peacock, J.; Peh, K.S.; Sheil, D.; Sunderland, T.; Swaine, M.D.; Taplin, J.; Taylor, D.; Thomas, S.C.; Votere, R.; Wöll, H. Increasing carbon storage in intact African tropical forests. Nature 2009, 457, 1003-1006.

[30] Phillips, O.L.; Malhi, Y.; Higuchi, N., Laurance, W.F.; Nunez, P.V.; Vasquez, R.M. ; Laurance, S.G. ; Ferreira, L.V. ; Stern, M. ; Brown, S. ; Grace, J. Changes in the carbon balance of tropical forests: evidence from long-term plots. Science 1998, 282:439-442.

[31] Brown, S. Estimating Biomass and Biomass Change of Tropical Forest: A primer. FAO Forestry Paper 134, Food and Agriculture Organization of the United Nations (FAO), Cambridge, Rome 1997.

[32] Chheng K. Reduced impact logging and its applications for sustainable forest management in Cambodia. Unpublished doctoral dissertation 2011, School of Biological Sciences, Universiti Sains Malasyia

[33] Kim, S.; Kim Phat, N.; Koike, M.; Hayashi, H. Estimating actual and potential Government revenues from timber harvesting in Cambodia. Forest Policy and Econ. 2006, 8, 625- 635.

[34] Murray, B.C.; McCarl, B.A.; Lee, H.C. Estimating leakage from forest carbon sequestration programs. Working Paper 02_06 May 2002. RTI International, 1-22p.

[35] UNFCCC (2008) Indicative simplified baseline and monitoring methodologies for selected small-scale CDM project activity categories: General guidance on leakage in biomass project activities (Version 03). Online publication accessed 19 July 2011. http://cdm.unfccc.int/Reference/Guidclarif/ssc/methSSC guid04.pdf

[36] World Bank, United Nations Development Program (UNDP), FAO. Cambodian Forest Policy Assessment. World Bank, Phnom Penh, 1996.

[37] DAI (Development Alternatives, Inc) Findings and Recommendations of the Log Monitoring and Logging Control Project. Reported submitted to the Royal Government of Cambodia. Department of Forestry and Wildlife, Phnom Penh, 1998.

[38] Asner, P.G.; Rudel, K.T.; Aide, T.M.; DeFries, R.; Emerson, R. A contemporary assessment of change in humid tropical forests. Conservation Biology 2009, 23, 1386-1395.

[39] Casson, A.; Obidzinski, K. From new order to regional autonomy: Shifting dynamics of "illegal" logging in Kalimantan, Indonesia. World Development 2002, 30, 2133-2151.

[40] Hamilton, K.; Chokkalingam, U. and Bendana M. State of the Forest Carbon Markets 2009: Taking Root \& Branching Out. Online publication accessed on 3 July 2011 at http://www.forest-trends.org/documents/files/doc 2384.pdf

\section{Copyright (C) 2011 by the author}

Contact: nopsasaki@gmail.com (Dr. Nophea Sasaki) 